\title{
Research and Statistics on Natural Disasters in Insurance and Reinsurance Companies
}

\author{
by Gerhard Berz *
}

\section{Introduction}

The exposure resulting from natural disasters is on the increase worldwide and is accompanied by a larger claims burden and a greater catastrophe risk for the insurance industry. This can be seen from the list of great natural disasters since 1960 (cf. encl. 1) which, in addition to the overall economic loss, shows the insured loss as well. More than half of the 56 major natural disasters listed here, namely 29 , are attributable to windstorm ; the rest are for the most part evenly distributed between earthquake and inundation, which although less frequent, have a considerably higher degree of catastrophe potential. However, coverage for windstorm losses is much more widespread throughout the world than coverage for the other natural disasters ; they are often included in other covers with no appreciable premium loading, e.g. in a fire policy or a motor own damage policy.

The significant rise in catastrophe exposure is due not only to the greater frequency of catastrophes, but to an even larger extent to the marked rise in loss potential. The main reasons for this trend are :

- the increase in the world's population and in insurance density;

- the concentration of people and insured property in conurbations ;

- the improved standard of living;

- the settlement in and industrialization of particularly exposed areas ;

- the introduction of less resistant building methods and more hazardous technologies.

This trend is most pronounced in the less developed countries whose national economies are particularly susceptible to the negative effects of natural disasters as has been demonstrated many times during the last few decades.

The local and international insurance markets are reacting slowly to the new situation. It is quite true that major natural catastrophes such as the San Francisco earthquake of 1906 have always unleashed extensive underwriting investigations and measures, but the

* Head of Natural Hazards Research Group, Munich Reinsurance Company, Munich. 
effects of such actions usually last only a few years. Only recently have various direct insurers and reinsurers introduced measures which are aimed at taking the drastically increasing catastrophe hazard into consideration.

The numerous research activities and evaluations which the individual insurance companies or markets conduct or have carried out for them are examples of this. These studies, i.e. scientific, mathematical/statistical, architectural or underwriting studies, can be divided into three main groups :

- risk assessment and rating;

- loss potential and accumulation control ;

- claims assessment, claims settlement and loss prevention.

These subjects will be discussed in detail in the following.

\section{Risk assessment and rating}

Before agreeing to provide cover, an insurer will always attempt to determine the probability of loss and the appropriate basic premium and to agree upon terms with the insured which will help to clarify the risk situation and make the risk acceptable. The prerequisite for this is sufficient information about the previous frequency and intensity of natural hazards at the location or in the country in question. In this connection, some insurers are able to consult data collections of their own, but this information is often not explicit enough and above all, does not go back far enough in time to permit a relatively reliable estimate of the probability of an occurrence. As a rule, there is only information about extreme events in the archives. Even though such catastrophic occurrences are of great importance for risk assessment, they give only a very limited insight into the risk as far as time and location are concerned. The extent of the basic premium is usually more strongly influenced by the relatively frequent occurrences of intermediate intensity.

A well-founded assessment of the hazard can only be made on the basis of scientific studies. In spite of their basic importance, such studies are only rarely conducted by the insurance companies themselves. The number of geoscientists employed by insurance companies is imperceptibly low (in the order of 10) and is almost exclusively to be found at the leading international reinsurance companies. These companies pass their research findings on to their clients as one of the services they offer. The bibliography will give an indication of the scope of these studies on natural hazards. An example of such a study is the Munich Reinsurance Company's "World Map of Natural Hazards" which makes it possible to read the degree of loss exposure from the quantitative details regarding frequency and thus to calculate the basic premium.

Usually, however, an insurer engages a consultant's office or a government institution (e.g. weather service) to draw up an expert's report for very important insured objects if he has not already received sufficient detailed information from the insured, or for less important objects and mass business, he uses the tariff guidelines of the specific insurance markets. In many countries such guidelines contain classifications of zones which show the geographic distribution of loss exposure and are based on corresponding scientific studies or on comprehensive loss statistics. A copy of the earthquake tariff map of the Turkish Insurance Association is enclosed as an example (cf. enclosure 2). The tariff zones 
often follow the political or administrative borders for reasons of better practical usage and therefore often deviate from the scientific exposure zones.

The premium necessary for an object which is to be insured is dependent not only on the frequency of losses but also on the loss susceptibility of the object. The latter is often directly related to the design of the loadbearing and non-loadbearing elements of buildings with regard to resistance to forces of nature. Proper design is often undermined by slipshod work during construction. The age of the building also plays a major role if adequate attention is not paid to consistent maintenance.

The technical appraisal needed here is above all the task of the engineers employed in relatively large numbers by insurance and reinsurance companies. The research done in this area is primarily concerned with the evaluation of damage to similar objects. When doing such work the companies draw on their own experience, loss reports from independent experts, reports in technical journals, lectures at conferences and of course the material provided by the insured and the engineering offices responsible for planning. For very large projects, representatives from the participating companies meet to try and establish a mutual basis for the assessment of premium calculation and the estimation of loss potential. It is sometimes even possible for the insurers to make the risk more acceptable by means of concrete constructional suggestions for improvement.

The field of new technologies poses the greatest problems since loss experience is either non-existent or very insufficient. Off-shore technology is an example of a field in which not only the most varied environmental influences first have to be studied, but also one in which the load bearing capacity of the systems can by no means be said to be known or secure. The numerous model calculations and laboratory tests in which extreme loads are simulated often lead to widely varying results. A great deal of know-how on the part of the insurer is required in the newest research sectors in order for him to make the proper assessment. The fact that the insurance industry moves forward very cautiously in this sector is not least dependent on "Murphy's law" which, in somewhat simplified terms, states that "if something can go wrong, it will" (sooner or later).

Deductibles are indispensable in the insurance of natural disasters since they make it possible to drastically reduce the vast number of minimal claims typical for natural disasters. The claims settlement costs and the overall loss amount can be reduced considerably. The effects on the premium rate can only be assessed and calculated correctly if the expected distribution of losses is fairly well known. For this reason it is one of the primary goals of research in the field of the insurance of natural disasters.

However, insurers do not like to speak about the losses they have suffered - this appears to be a general characteristic of all economic enterprises - and they are very reluctant to publish corresponding statistics. With the exception of a few countries in which the claims settlement following a natural disaster is conducted by centralized organizations of the insurance industry, as is the case in the USA, Australia and Japan, these figures are not even known within the insurance industry. The loss statistics are usually limited to the ratio between losses and premiums; in individual cases average loss ratios (relationship between losses and the sums insured) are available. On this basis, various relationships between the event intensity (e.g. windspeed or earthquake intensity) and the loss ratio dependent upon specific constructional characteristics are arrived at without an even tolerably satisfactory level of information having been reached. Almost no reliable data is 
available for the fields of nonstructural losses and the damage to the contents of buildings, e.g. furnishings, machines, installations, goods. A similarly unsatisfactory amount of information is available about consequential losses, e.g. fire as a consequence of earthquake, or about losses which occur during the construction period. These questions must now in any case be given particular attention by the insurance industry's experts for natural disasters.

\section{Loss potential and accumulation control}

As already mentioned in the introduction, the main problem in insuring elemental perils is the enormous loss potential of major natural catastrophes. While the insured losses of previous catastrophes have repeatedly amounted to hundreds of millions of US dollars, and in individual cases have almost reached the billion dollar mark (Hurricane Betsy 1965 : US\$ 715 million, Hurricane Frederic 1979: US\$ 750 million), there are a number of probable catastrophes for which it can be assumed with certainty that the loss amounts will be many times higher than the sums just mentioned. The following are examples of such probable catastrophes:

- A repetition of the San Francisco earthquake of 1906 or a major earthquake in the Los Angeles area would, according to today's estimates, cause total losses of between US\$50 and 100 billion. In spite of low earthquake insurance density, the insured losses in both cases could amount to several billion dollars.

- A repetition of the Tokyo earthquake of 1923 would probably cost about US\$250 billion today. At present the payments by the insurance industry for dwelling risks are limited to approx. US\$ 5 billion. No such total loss limit exists for industrial business, however, the maximum indemnification payments provided for in the treaties amount to only $15-30 \%$ of the insured value in the most exposed zones. In view of the extraordinarily high exposure of the majority of areas that serve as industrial centers, this means an additional loss potential in the billions.

- The damage that "Betsy" caused in 1965 would cost the insurance industry approx. US\$ 2 billion today. The insured loss of a one-hundred-year-hurricane would be estimated at even 3 to 4 times this amount.

- Numerous other insurance markets with high concentrations of values are also exposed to catastrophic losses in the billions, e.g. Mexico, Venezuela, Carrada and New Zealand with regard to earthquake, Australia and Japan with regard to tropical cyclones, Central and Western Europe with regard to extra-tropical storms, storm surges and inundations.

Loss potential has thus reached an extent that makes detailed underwriting investigations urgently necessary. The focal points of catastrophe exposure, some of which were mentioned above, must be investigated immediately - if this has not already been done - by scientists, construction engineers, underwriters and the authorities in order to determine what areas could be affected by a single extreme event and what distribution of loss intensity is to be expected. When drawing up such catastrophe scenarios, a great deal naturally depends on what probability of occurrence or what recurrence period is used as a basis. This is not so much a scientific question as a business policy decision.

The areas most exposed to catastrophes must be subdivided into a suitable number of so-called accumulation assessment zones which make it possible to simulate the 
distribution of losses and which, above all, assess the particularly exposed areas such as coastal strips or areas with very high insurance density separately. The liabilities determined per accumulation assessment zone should be classified where possible according to their loss susceptibility so that individual average loss ratios can be applied per class of liability and accumulation assessment zone. On the basis of these liability statistics per accumulation assessment zone, the loss areas - called loss accumulation zones in the insurance industry - and the loss distribution of various alternative catastrophe events can be simulated. The probable maximum loss per loss accumulation zone is then the sum of the losses in the individual accumulation assessment zones.

This system of accumulation control can serve its purpose only if a country's entire insurance market can reach an agreement on a uniform division into accumulation assessment zones. In the "CRESTA" (Catastrophe Risk Evaluating and Standardizing Target Accumulations) programme, a group of direct insurers and reinsurers has committed itself to the compilation of scientific and underwriting factors of catastrophe exposure in a number of countries, in particular in Latin America, and to the introduction of the system of accumulation control described above. The relevant material for Mexico is enclosed as a particularly detailed example (cf. enclosure 3 ).

\section{Claims assessment, claims settlement and loss prevention}

Losses make insurance necessary and there is no better advertisement for insurance than the smooth and correct settlement of claims. For precisely this reason it is important for the insurance industry to organize claims assessment and claims settlement as effectively as possible and at the same time provide knowledgeable assistance with regard to loss prevention. Of importance in this connection is the scientific and technical research into the causes of losses and the previously mentioned evaluation of loss statistics.

After a normal loss, a claims adjuster will limit himself to an examination of the loss advice in connection with the basic policy wording and perhaps undertake a brief loss inspection. In contrast, where high claims amounts are concerned a scientific and/or constructional expert's report or an investigation of one's own may become necessary. In this context, one usually has to ask whether a causal connection exists between the natural disaster and the loss, whether the insured object was maintained according to the terms of the contract before the loss occurred, whether the extent of the claims for indemnification is justified and, last but not least, whether there is any contributory negligence on the part of the insured. The insurer cannot be expected to accept a loss which is the result of negligence or is caused wilfully.

The following will illustrate this situation:

In the course of the construction of a gas pipeline in North Africa, a sandstorm caused an open trench $68 \mathrm{~km}$ long to become filled up by flying sand and drifting excavated material. The re-excavation which then became necessary incurred costs of approx. US\$ 350,000 , which the contractor felt were covered under the erection all risks policy. As it turned out during the subsequent meteorological investigation, wind forces of 5 or more, thus causing sand drifts or sand storms, could be expected in this area on an average of 35-50 days a year. The contractor should therefore have excavated the trench only in short segments and for short periods of time. The claim was thus rejected as having been foreseeable. 
Insurers and adjusters throughout the world are faced with thousands of such problematic claims cases. The situation always becomes particularly critical when a large number of insured objects are affected simultaneously, i.e. when a natural disaster occurs. For example, in the USA in 1979 there were more than 100,000 claims to be settled after hurricane "Frederic" has passed. Thanks to a sophisticated loss registration system, the insurance industry was able to obtain an exact idea of the probable extent of damage within 36 hours. The American Insurance Association's model loss adjustment system made it possible to settle $80 \%$ of a claims burden totalling US\$ 750 million within just three weeks. In this context, it was certainly a great help that the population had been informed immediately by the press and television of all measures required to determine advise and minimize losses.

The costs for all of these measures are usually minimal. For example, in Darwin in 1974 when forty first-class loss adjusters handled approx. 15,000 losses within 6 months, the costs amounted to only $2 \%$ of the overall insured loss. Moreover, the resistance of buildings against windstorms, which had proved to be completely inadequate, was improved considerably after the cyclone when the experience of the loss adjusters was made use of.

Methods of construction which can withstand all conceivable forces of nature absolutely cannot be attained at economically justifiable costs. More careful attention to details during the designing phase would undoubtedly help prevent numerous losses without increasing costs substantially. And yet, even if current construction standards in many countries guarantee sufficient security for new buildings, this does not of course apply for the great number of old and poorly maintained buildings in an insurer's portfolio. In this connection emphasis must be placed on loss prevention. Other problem areas include vulnerable structures during the construction phase (e.g. bridge construction in an area exposed to windstorm or earthquake) which are seldom dealt with in building regulations and the new technologies mentioned earlier.

The insurer has some means to loss prevention at his disposal, e.g. risk inspection, the conveyance of technical information and loss experience to the insured, the setting up of alarm systems in co-operation with major industrial clients, participation in the formulation of building regulations and, above all, public relations efforts to make the customer aware of problems connected with natural disasters and to awaken or maintain his willingness to implement loss prevention measures.

These various possibilities make it attractive and worthwhile for the insurer to invest in his own research institutes and activities, which thus benefit himself, the insured and the economy as a whole. The increase in the amount of research work done in this sector within the past few years is an indicator of this.

\section{Bibliography}

Allianz Versicherungs-AG : Der Maschinenschaden. - Berlin/Munich.

American Insurance Association, Property Claim Services : Catastrophe Loss Adjustment Procedure. - New York. 
Ammann, W. and Porro, B. (1982): The Earthquake in Southern Italy of 23 November 1980 - Engineering Aspects and Interpretation of Building Damage. - 7th European Conference on Earthquake Engineering, Athens.

Assemblée Plénière des Sociétés d'Assurances (1981): La garantie des séismes: théorie et pratique. - Paris.

Associazione Nazionale fra le Imprese Assicuratrici (1982): Assicurazione Terremoto: Progretto di Disciplina. - Milano.

Auriac d', C. E. (1969) : L'assurance des tempêtes, ouragans, trombes, tornades, cyclones. - L'Argus, Paris.

Bertrand, M. (1976) : Climatologie et assurance. - L'Argus, Paris.

Berz, G. (1977) : Catastrophe Potential: Simulation and Control. - 2nd International Conference on Structural Safety and Reliability, Munich.

Berz, G. (1978) : Earthquake Loss Accumulation Control. - International Symposium on the February 4th, 1976 Guatemalan Earthquake and Reconstruction Process, Guatemala.

Berz, G. (1979) : Die Winterschäden 1978/79 in Norddeutschland aus meteorologischer und physikalischer Sicht. - Schadenspiegel, 22, Munich.

Berz, G. and Voorduin, M. (1980): David - The Effects of a Great Hurricane. Schadenspiegel, 2/23, Munich.

Berz, G. and Smolka, A. (1980) : A World Map of Seismic Risk and its Application to Insurance. - 7th World Conference on Earthquake Engineering, Istanbul.

Berz, G. (1981) : Tornadoes. - Schadenspiegel, 2/24, Munich.

Board of Fire Underwriters of the Pacific (1925) : Notes of Interest to Underwriters on Earthquake Damage to the City of Santa Barbara, California. - San Francisco.

Bourthoumieux, J. (1979): Le contrôle des cumuls des risques annexes du point de vue de la réassurance. - L'Assurance Française, 10/79, Paris.

Butler, J. S. (1980) : Defining “Any One Event ”. - Reinsurance, London.

Cámara de Aseguradores de la República Dominicana (1979) : Huracán David. - Santo Domingo.

Central American Actuarial Association (1977): The Experience on Earthquake Risk in Central America. - Astin Bulletin, 3/IX, Leiden/Holland.

Cole, R. (1977) : Natural and Man-Made Catastrophes. - Policy, London.

Collon, R, (1955): The Reinsurance of Hail Risks. - The Review, London.

Commercial Union Assurance Company Ltd. (1975): Earthquake and Windstorm. London.

Commission Incendie du Comité Européen des Assurances (1982): Risques de tremblements de terre, - Istanbul.

Conrad, K. (1979); Contrôle des accumulations sur les risques naturels: l'aspect scientifique d'un problème d'assurance et de réassurance. - L'Assurance Française, 10/79, Paris.

Coppola, E. (1979): Couverture des risques de catastrophes provoquées par les calamités naturelles et les risques politiques. - L'Assurance Française, 11/79, Paris. 
CRESTA (1982): A Summary of All Known Facts about Countries where Catastrophic Risks Are Concerned. - Zürich.

Cummins, J., Shpilberg, D. and Roy, Y. (1978): A Stochastic Simulation Model for Reinsurance Decision Making by Ceding Companies: A Venezuelan Case Study. International Insurance Seminars, Manila.

Dörr, R. R. (1977) : Nichtproportionale Rückversicherung - Windstürme in Nordeuropa.

- Zeitschrift für Versicherungswesen, Hamburg.

Dörr, R. R. (1978) : Earthquake. - International Insurance Seminars, Manila.

Driscoll, D. (1979): Problems of Earthquake Insurance. - UNDRO Newsletter, 9/79, Geneva.

English, R. (1980): A Theoretical Approach to Establishing an Earthquake Tariff. Foresight, 8/V, London.

Esteva, J. L. (1979) : Vulnerabilidad y daños. - I. Foro Mundial sobre el "Impacto financiero del riesgo sismico", Caracas.

Estrada, G. (1981) : Microzonacion de Bogota. - Reaseguradora de Colombia, Bogota.

Factory Mutual Engineering Corp. (1979) : Loss Prevention Data. - Boston.

Franck, L. (1979): On the Reinsurance of the Catastrophe Risks. - Zeitschrift für Versicherungswesen, Hamburg.

Franzosini, G. F. and Sciullara, G. (1980): Un Evento Catastrofico: Il Terremoto. Phenix-Soleil, Roma.

Freeman, J. R. (1932) : Earthquake Damage and Earthquake Insurance. - McGraw-Hill, New York.

Frey, E. (1965): Möglichkeiten und Grenzen der Versicherung von Katastrophen. Zeitschrift für die gesamte Versicherungswirtschaft, Berlin.

Friedman, D. G. (1972) : Insurance and the Natural Hazards. - The Astin Bulletin, 7/4, Leiden/Holland.

Friedman, D. G. (1975): Computer Simulation in Natural Hazard Assessment. University of Colorado, Boulder/USA.

Friedman, D. G. (1976) : Hail Suppression Impact upon Property Insurance. - Technology Assessment of the Suppression of Hail, Illinois State Water Survey, Urbana/USA.

Friedman, D. G. (1979) : Economic Impact of Windstorms in the United States. - 5th International Conference on Wind Engineering, Fort Collins/USA.

Gerathewohl, K. et al. (1980) : Reinsurance - Principles and Practice. - Karlsruhe.

Gerathewohl, K. and Nierhaus, F. (1981): Les limites d'assurabilité des risques catastrophiques. - L'Argus, 25, Paris.

Guerra, R. and Esteva, L. (1976) : Estimacion de daños maximos causados por un evento sismico en la Republica Mexicana. - Asociacion Mexicana de Instituciones de Seguros, Mexico.

Gürpinar, A. and Yücemen, S. M. (1980) : An Obligatory Earthquake Insurance Model for Turkey. - Proceedings of the Int. Conf. on Engineering for Protection from Natural Disasters, Bangkok. 
Hellberg, M. (1978): The Effect of Earthquake Prediction on Earthquake Insurance in New Zealand. - Bulletin of the N.Z. National Society for Earthquake Engineering, 11 , Wellington.

Hendricks, R. L. and Friedman, D. G. (1966) : Potential Impacts of Storm Modification on the Insurance Industry. - Dept. of Geography, Research Paper No. 105, University of Chicago Press, Chicago.

Husid, R. (1971): Terremotos/Earthquakes. - Revista Mexicana de Seguros, Mexico.

Insurance Council of Australia (1979): Insurance Emergency Service. - Melbourne.

Insurance Council of Australia (1980): National Insurance Emergency Services Agreement. - Melbourne.

Insurance Information Institute (Annual) : Insurance Facts, Section 6 : Losses by Category. - New York.

Jaggar, T. A. (1925) : Earthquake Insurance. - Matériaux pour l'étude des calamités, 7, Geneva.

Kaplan, M. (1971) : Actuarial Aspects of Flood and Earthquake Insurance. - Proceedings of the Conference of Actuaries in Public Practice, XXI.

Kiln, R. J. (1975) : A “Darwin ” Had to Happen. - The Review, London.

Kohler, W. (1977) : Analysis and Acceptance of Risks from an Underwriter's Point of View. - 2nd International Conference on Structural Safety and Reliability, Munich.

Kubo, T. (1978): Speedy Claims Handling in Heavy Earthquake Disaster. - Japan Insurance News, 27, Tokyo.

Kulhánek, O. and Båth, M. (1976) : Earthquake Insurance Coefficients with Application to Some South-Central American Capitals. - Uppsala.

Kunreuther, H. C. et al. (1978) : Disaster Insurance Protection : Public Policy Lessons. Wiley Interscience, New York.

Landin, D. (1975) : Catastrophes in the United States. - Reinsurance, 6, London.

Lanz-Stauffer, H, and Rommel, C. (1936) : Elementarschäden und Versicherung. - Bern.

Leicester, R. H. et al. (1979) : An Assessment of Potential Cyclone Damage to Dwellings in Australia. - 5th International Conference on Wind Engineering, Fort Collins/USA.

Lloyd's Weekly Casualty Reports. - London.

Lockett, J. (1980) : Catastrophes and Catastrophe Insurance. - Journal of the Actuaries Students Society, 24, London.

McCrindell, A. L. (1972): The Insurability of Natural Catastrophes. - Journal of the Chartered Insurance Institute, 69, London.

Mohr, H. H. and Engel, W. (1970) : Grundlagen der Sturmversicherung. - Karlsruhe.

Münchener Rückversicherungs-Gesellschaft : Schadenspiegel - Losses and Prevention. Munich.

Münchener Rückversicherungs-Gesellschaft (1973) : Sturmschäden in Europa. - Munich. 
Münchener Rückversicherungs-Gesellschaft (1973): Managua - A Study of the 1972 Earthquake. - Munich.

Münchener Rückversicherungs-Gesellschaft (1973) : Earthquakes. - Munich.

Münchener Rückversicherungs-Gesellschaft (1973) : Crop Insurance. - Munich.

Münchener Rückversicherungs-Gesellschaft (1974) : Flood-Inundation. - Munich.

Münchener Rückversicherungs-Gesellschaft (1975): FIFI - A Study of the Hurricane Damage in Honduras, 1974. - Munich.

Münchener Rückversicherungs-Gesellschaft (1976) : Der Capella-Orkan - Januarstürme 1976 über Europa. - Munich.

Münchener Rückversicherungs-Gesellschaft (1976) : Guatemala '76 - Earthquakes of the Caribbean Plate. - Munich.

Münchener Rückversicherungs-Gesellschaft (1978): World Map of Natural Hazards (in English, German, French and Spanish. Explanatory Booklet and Catastrophe Catalogue). - Munich.

Münchener Rückversicherungs-Gesellschaft (1979): Earthquake Research in China. Munich.

Münchener Rückversicherungs-Gesellschaft (1981) : Earthquake Accumulation Control Fire Insurance. - Munich.

Münchener Rückversicherungs-Gesellschaft (1982): Loss Adjustment after Natural Disasters. - Munich.

National Board of Fire Underwriters (1906): The San Francisco Conflagration of April 1906. - San Francisco.

National Board of Fire Underwriters (1933): Report on the Southern California Earthquake of March 10, 1933. - San Francisco.

National Board of Fire Underwriters and Pacific Fire Rating Bureau (1964): The Alaska Earthquake. - San Francisco.

Neave, J. (1979): The Reinsurance of Extraneous Perils. - L'Argus, 13, Paris.

Negrier, F. (1979): Approaches to Low-Frequency High-Severity Social Exposures and Insurance Requirements. - International Insurance Seminar, Dallas.

Novaro, G. (1982): Terremoto. - Revista Mexicana de Seguros, Mexico.

O'Riordan, T. (1974): The New Zealand Natural Hazard Insurance Scheme : Application to North America. - in White, G. F. (1974) : Natural Hazards.

Peñuela, A. (1981): Aproximacion al cumulo de la maxima perdida probable de las construcciones en Bogota para el riesgo de terremoto. - Reaseguradora de Colombia, Bogota.

Perrenoud, P. Cl. and Straub, E. (1976): Insurance and the Economic Consequences of Earthquakes. - Unesco Conference on the Assessment and Mitigation of Earthquake Risk, Paris.

Perrenoud, P. Cl. (1979): Quelques réflexions sur l'assurance du risque de tremblement de terre dans le monde. - L'Argus International, 13, Paris. 
Porro, B. (1979) : Le contrôle des cumuls provenant des risques à caractère catastrophique. - L'Argus International, 13, Paris.

Ramirez, J. and Estrada, G. (1977) : Mapa de riesgo sismico de Colombia. - Reasegaradora de Colombia, Bogota.

Reinsurance Offices Association (1973): Earthquakes - Managua and after. - London.

Reinsurance Offices Association (1975): Darwin - Tracy and after. - London.

Reinsurance Offices Association (1975): Earthquake Risks: California, Israel, Puerto Rico. - London.

Reinsurance Offices Association (1975) : Jamaica - An Earthquake Study. - London.

Reinsurance Offices Association (1975): Trinidad and Tobago - Earthquake Report. London.

Reinsurance Offices Association (1976): Earthquakes - A General Introduction. London.

Reinsurance Offices Association (1977): Earthquake Study Australia. - London.

Reinsurance Offices Association (1977): Earthquake Study Mexico. - London.

Reinsurance Offices Association (1978) : Earthquake Study Ecuador. - London.

Reinsurance Offices Association (1978) : Earthquake Study Venezuela. - London.

Reinsurance Offices Association (1980) : Introduction to Tropical Storms. - London.

Reinsurance Offices Association (1982) : Earthquake Study Central America. - London.

Ryder, J. M. and Kimber, D. J. (1977) : Earthquakes and Windstorms - Natural Disasters. - Astin Bulletin, 3/IX, Leiden/Holland.

Sauter, F. F. and Shah, H. C. (1978): Estudio de seguro contra terremoto. - Instituto Nacional de Seguros, San José/Costa Rica.

Sauter, F. F. (1979): Damage Prediction for Earthquake Insurance. - 2nd US National Conference on Earthquake Engineering, Stanford/USA.

Schweizerische Rückversicherungs-Gesellschaft : Engineering Bulletin. - Zürich.

Schweizerische Rückversicherungs-Gesellschaft : SR-Focus. - Zürich.

Schweizerische Rückversicherungs-Gesellschaft (Annual): Natural Catastrophes and Major Losses. - Sigma, Zürich.

Schweizerische Rückversicherungs-Gesellschaft (1969): The Earth's Crust in Movement. - Zürich.

Schweizerische Rückversicherungs-Gesellschaft (1976): Rain, Inundation and Flood in C.A.R. and E.A.R. Insurance and Reinsurance. - Engineering Bulletin, Zürich.

Schweizerische Rückversicherungs-Gesellschaft (1977): De uberrima fide et terrae motu. - Zürich.

Schweizerische Rückversicherungs-Gesellschaft (1978): Atlas on Seismicity and Volcanism. - Zürich.

Schweizerische Rückversicherungs-Gesellschaft (1977/1982): A Short Guideline to Earthquake Risk Assessment. - Zürich. 
Shenhav, Y. (1977): Towards an "International Insurance Fund " : A Tool for Mitigation of Extra-Hazard Risks. - Astin Bulletin, 3/IX, Leiden/Holland.

Sherburd, J.G. (1981): The Settlement of Insurance Claims Following a Large Earthquake. - Large Earthquakes in New Zealand, Miscellaneous Series No. 5, Royal Society of N.Z., Wellington.

Shpilberg, D. and Herrera, R. (1977) : Earthquake Simulation, Decision Analysis and Reinsurance : A Look at Venezuela. - 23rd International Meeting of the Institute of Management Science, Athens.

Shpilberg, D. (1979): Administración del riesgo sismico. - I. Foro Mundial sobre el "Impacto financiero del riesgo sismico", Caracas.

Skandia Insurance Company (1975): Earthquake and Insurance. - Annual Report, Stockholm.

Skandia Insurance Company (1978): The Tuve Landslide. - Os Emellan, 5/78, Stockholm.

Smolka, A. and Berz, G. (1981) : Methodology of Hazard Mapping - Requirements of the Insurance Industry. - Bulletin of the International Association of Engineering Geology, 23, Krefeld.

Smolka, A. (1982) : Cartographie des risques naturels pour réassureurs. - Commissariat à l'étude et la prévention des risques naturels majeurs, Paris.

Société Commerciale de Réassurance (1977): Quand la terre tremble. - L'Argus, Paris.

Sofonea, T. (1977) : Drei große historische Erdbeben aus der Sicht der Versicherung. Schriftreihe des Seminars für Versicherungsbetriebslehre an der Universität München, Heft 94, München.

Splittgerber, E. (1977): Research into the Causes of Damage and its Significance for the Reliability of Technical Systems. - 2nd International Conference on Structural Safety and Reliability, Munich.

State of California, Insurance Dept. (1981): California Earthquake Zoning and Probable Maximum Loss Evaluation Program. - San Francisco.

Staveley, J. K. (1977): A Natural Disaster Scheme for Australia. - Reinsurance, 8, London.

Steinbrugge, K. V. et al. (1971): San Fernando Earthquake, February 9, 1971. - Pacific Fire Rating Bureau, San Francisco.

Steinbrugge, K. V. et al. (1972) : Earthquake and Earthquake Insurance. - Fireman's Fund Insurance Company, San Francisco.

Steinbrugge, K. V. (1973): On Earthquake Insurance Losses for Single Family Wood Frame Dwellings. - Insurance Services Office, San Francisco.

Taylor, G. C. (1974): Rate making for Insurance of Disastrous Events. - Macquarie University, School of Economic and Financial Studies, Research Paper No. 56, Sydney.

Themptander, R. (1978) : Earthquake and Insurance. - 2nd International Conference on Microzonation for Safer Construction, San Francisco. 
Tiedemann, H. (1980): A Statistical Evaluation of the Importance of Non-Structural Damage to Buildings. - 7th World Conference on Earthquake Engineering, Istanbul.

Tiedemann, H. (1981) : Building Quality and Earthquake Damage - Some Statistics of the South Italian and Algerian Earthquakes of Nov. 23, 1980 and Oct. 10, 1980. National Symposium on Earthquake Disaster Mitigation, Roorkee/India.

Tiedemann, H. (1982) : Structural and Nonstructural Damage Related to Building Quality. - 7th European Conference on Earthquake Engineering, Athens.

Toledo, R. (1982): Introduccion a la problematica de seguros contra riesgos catastroficos. - Revista Iberoamericana de Seguros, 2/82.

Toplis \& Harding (1973): Managuan Earthquake Disaster. - London.

Toplis \& Harding (1975): Cyclone Tracy. - London.

Toplis \& Harding (1979) : Hurricanes "David" and "Frederic". - London.

Under 35's Reinsurance Group (1978): Catastrophe '78. - London.

Unesco (1972): Consultative Meeting of Experts on the Statistical Study of Natural Hazards and their Consequences - Report. - Paris.

Unesco (1977) : Working Group of the Economic Implications of Earthquake Risk - Final Report. - Paris.

Unesco (1978): International Seminar on Earthquake Hazards and Insurance - Final Report. - Paris.

U.S. Dept. of Housing and Urban Development, Federal Insurance Administration (1976) : National Flood Insurance Program Regulations. - Federal Register, Vol. 41, No. 207, Washington.

Vaughan, J. K. (1971) : Notes on Insurance against Loss from Natural Hazards. - N.H.R. Paper No. 21, University of Colorado, Boulder.

Vischer, H. B. (1970): The Insurance and Reinsurance of Natural Catastrophe International Insurance Monitor, New York.

Vischer, M. (1976) : Comment apprécier et contrôler le risque de tremblement de terre? - La Réassurance, Paris.

Wakuri, M. (1977) : Windstorm Coverage in Japan. - Astin Bulletin, 3/IX, Leiden/Holland. Wakuri, M. (1977) : Earthquake Insurance in Japan. - Astin Bulletin, 3/IX, Leiden/Holland. White, G. F. (1974) : Natural Hazards : Local, National, Global. - Oxford University Press, New York.

Wiggins, J. H. Company (1981) : Earthquake Insurance: A Public Policy Analysis. Federal Insurance Administration, Washington D.C.

Wiggins, J. H. Company (1981): Earthquake Insurance Practices. - Federal Insurance Administration, Washington, D.C.

Wiggins, J. H. Company (1981) : Federal Disaster Assistance and Earthquake Insurance : Problems and Proposals. - Federal Insurance Administration, Washington D.C.

Wilders, P. J. (1969): Weathering the Storm - Catastrophe Records Examined. Reinsurance, 1, London.

Wilders, P. J. (1970): The Re-insurability of Catastrophes. - Reinsurance, 2, London. 
Enclosure 1 : List of great natural disasters since 1960

Date

29th Feb, 1960

21st May, 1960

September 1960

September 1961

February 1962

November 1962

26th July, 1963

28th March, 1964

16th May, 1964

November 1964

September 1965

November 1966

February 1967

August 1969

31 st May, 1970

August 1970

12th Nov., 1970

9th Feb., 1971 June 1972

November 1972

23rd Dec., 1972 April 1974

September 1974

December 1974

January 1976

4th Feb., 1976

6th May, 1976

May 1976

28th July, 1976

17th Aug., 1976

4th March, 1977

12th June, 1978

15th April, 1979

August 1979

September 1979

May 1980

August 1980

10th Oct., 1980

23rd Nov., 1980

24th Feb., 1981 May 1981

28th July, 1981

November 1981

January 1982 April 1982

November 1982

November 1982

13th Dec. 1982

Jan./March 1983

Jan./April 1983

February 1983

4th March, 1983

31 st March, 1983

26th May, 1983

August 1983

August 1983
Event

Earthquake

Earthquake

Hurricane "Donna"

Hurricane "Carla"

Storm surge

Typhoon "Karen"

Earthquake

Earthquake

Earthquake

Typhoon "Louise"

Hurricane "Betsy"

Inundation

Winter gale

Hurricane "Camille"

Earthquake

Hurricane "Celia"

Cyclone

Earthquake

Hurricane "Agnes"

Winter gale

Earthquake

Tornadoes

Hurricane "Fifi"

Cyclone "Tracy"

Winter gale

Earthquake

Earthquake

Typhoon "Pamela"

Earthquake

Earthquake

Earthquake

Earthquake

Earthquake

Hurricane "David"

Hurricane "Frederic"

Eruption Mt St Helens

Hurricane "Allen"

Earthquake

Earthquake

Earthquake

Hail, tornadoes

Hailstorm

Winter gale

Winter gales

Tornadoes

Winter gale

Hurricane "Iwa"

Earthquake

Gales

Floods

Bushfire

Cyclone "Oscar"

Earthquake

Earthquake

Hurricane "Alicia "

Floods
Area

Morocco
Chile
USA
USA
Germany
Guam
Yugoslavia
Alaska
Japan
Philippines
USA
Italy
Germany
USA
Peru
USA
East Pakistan
USA
USA
Central Europe
Nicaragua
USA
Honduras
Australia
Europe
Guatemala
Italy
Guam
China
Philippines
Romania
Japan

Japan

Yugoslavia, Montenegro

Caribbean and USA

USA

USA

Caribbean and USA

Algeria

Italy

Greece

USA

Canada

Denmark

USA

USA

France

Hawaii

Yemen

USA

Peru, Ecuador

Australia

Fiji

Kolumbien

Japan

USA

Spain

$\begin{array}{ccc}\begin{array}{c}\text { Number } \\ \text { of persons } \\ \text { killed }\end{array} & \begin{array}{c}\text { Overall } \\ \text { losses } \\ \text { in million } \\ \text { US\$ }\end{array} & \begin{array}{c}\text { Insured } \\ \text { losses } \\ \text { in million }\end{array} \\ \text { US\$ }\end{array}$

13,100

120

417

426

570

600

250

300

540

800

600

1,420

1,300

300

1,400

510

450

100

535
3,100

420
800

800
1,000

1,000
500

500

1,300

1,100

2,000

120

110

800

1,800

2,700

2,000

2,300

2,700

1,400

250

2,590

3,114

approx 3,000

approx 10,000

900

$$
91
$$

100

10

30

20

50

715

50

225

330

50

100

200

100

430

20

300

500

55

66

2

250

750

27

50

40

20

$250 \quad 95$

$1,000 \quad 345$

245

$280 \quad 150$

$234 \quad 137$

90

525

100

$230 \quad 151$

$70 \quad 30$

380

600

1,650

3,300 
Enclosure 2 : Earthquake exposure zones, Turkey

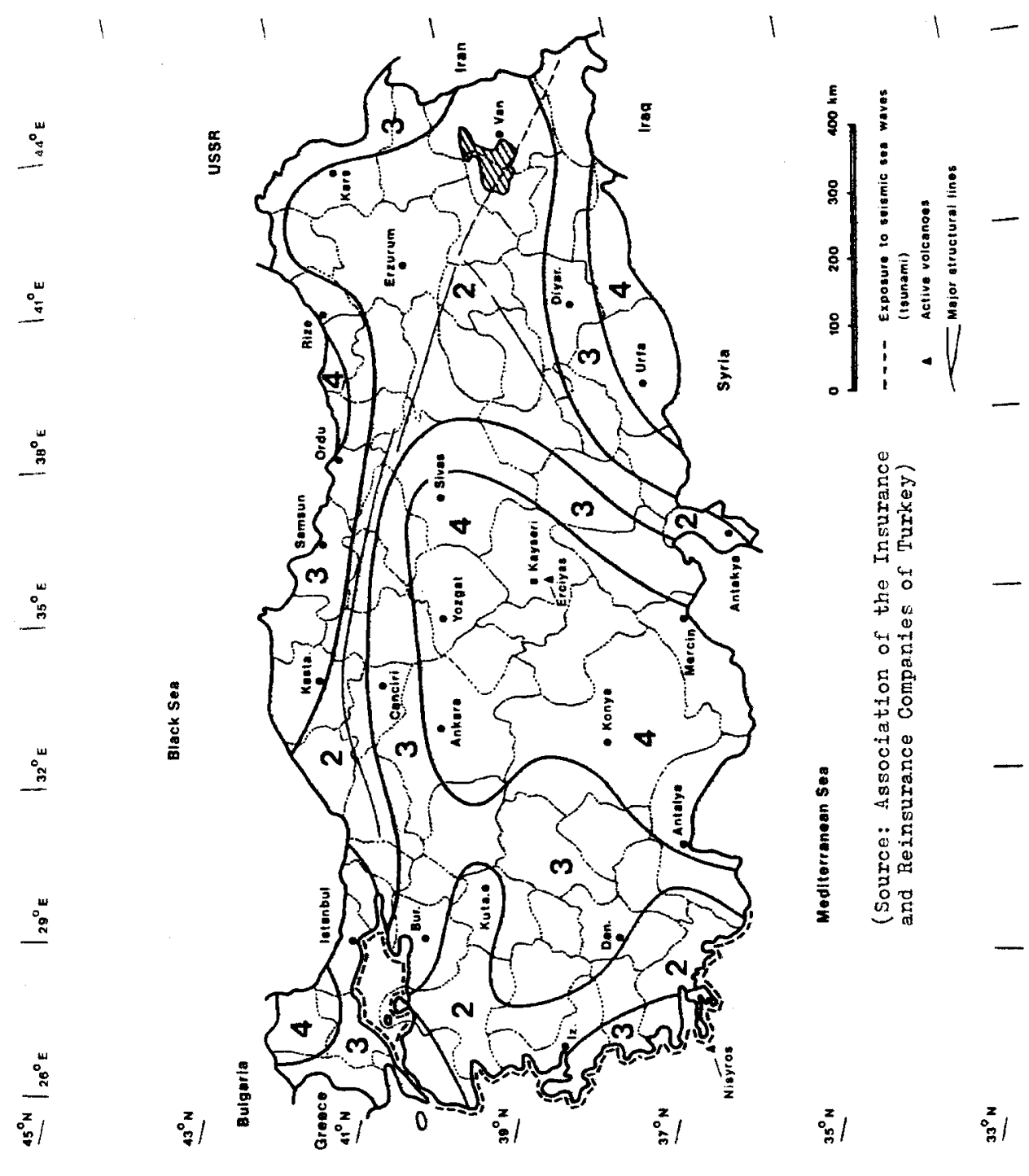




\section{Enclosure 3 : Summary of earthquake situation}

Date : 23.9 .82

COUNTRY : Mexico

GENERAL ASPECTS

Geology: Cocos plate moving underneath the Caribbean plate and, more to the north, is rubbing against the North American plate.

Subsoil: Particularly unfavourable in Valle de México (former lake).

History: 1907 M 8.3; 1908 M 8.1 ; 1912 M $7.8 ; 1928$ M 7.5; 1957 M 7.7.

Return periods : Mexico City : MM VII : 25 years ; MM VIII : 85 years ; MM IX : 320 years.

Building codes : 1957 "Primer Código"; 1962 : Codes for México, D.F. and Acapulco ; 1966: Last revision of code for the City of Mexico.

\section{INSURANCE COVER}

Clauses : Fire following Earthquake automatically included in Fire policy ; special clause for damage caused by shock.

Tariffs: Average of $1 \%$ for "Valle de México".

Coinsurance : $25 \%$.

Deductible : $2 \%$ of $75 \%$.

Max. accumulation insured: Approx. US\$20,000 m. (for $100 \%$ s.i. Fire) in Valle de México (1980).

\section{SPECIAL PROVISIONS FOR INSURANCE COMPANIES}

Information: Yes, compulsory.

Separation: Yes.

Protection: At least $12 \%$ of accumulations for own account in Valle de México plus Acapulco must be covered by special reserves and excess of loss programme.

Reserves: $60 \%$ of Earthquake premiums for own account must be allocated to special reserve fund (accumulative).

Commission for agents : $18 \%$ of Earthquake premium.

\section{REINSURANCE}

Information: Quarterly reporting on accumulations. Uniform system as from 1.1.77, but figures on this basis still not available.

Separation: Yes.

Commission : $35 \%$.

Additional commission: None.

Profit commission: None.

Underwriting limit: Yes, indicative, for zone "Valle de México", obligation to advise when accumulations reach $80 \%$.

Parallel cessions: In almost all companies.

WXL cover unlimited: None. 


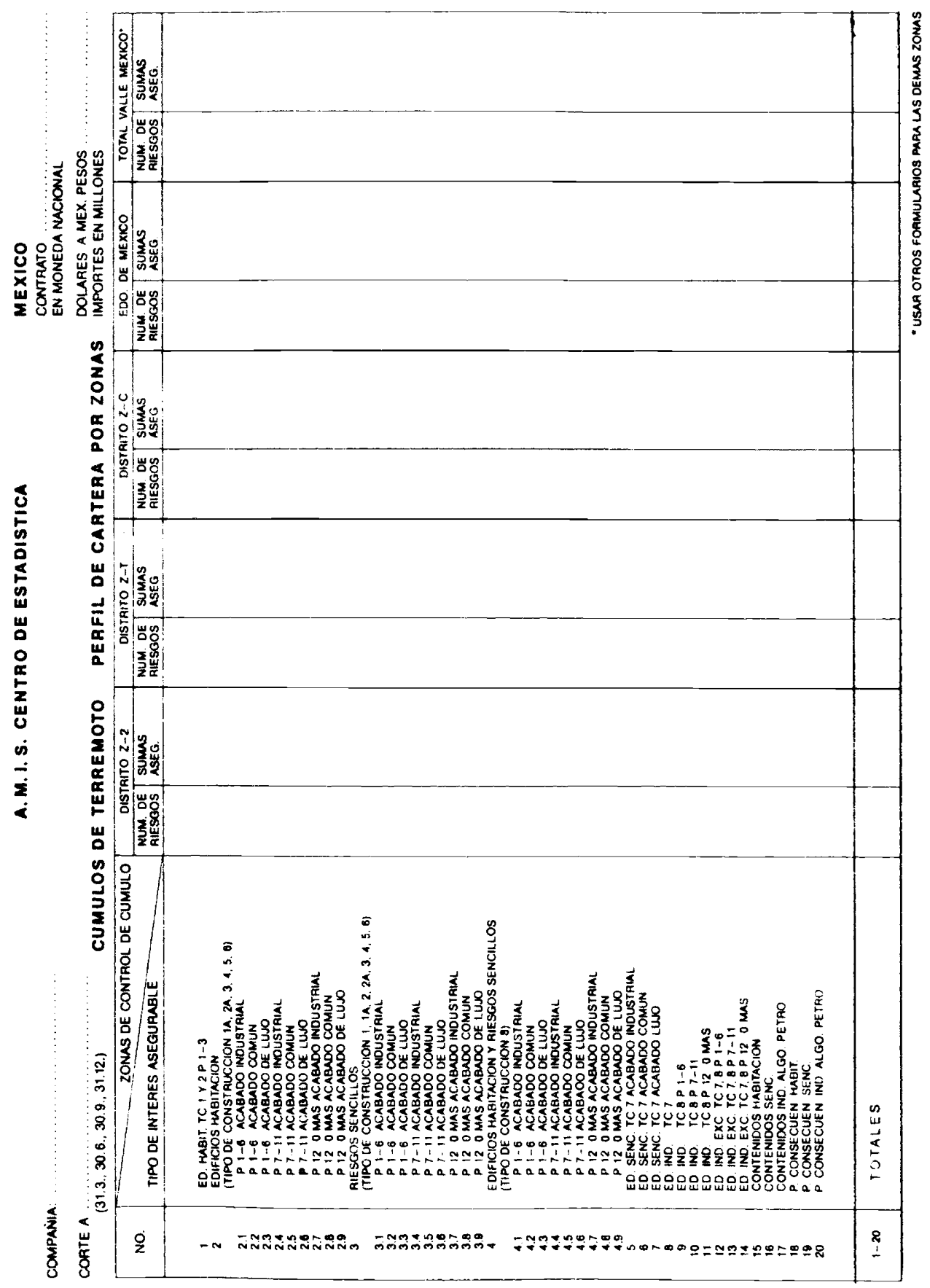




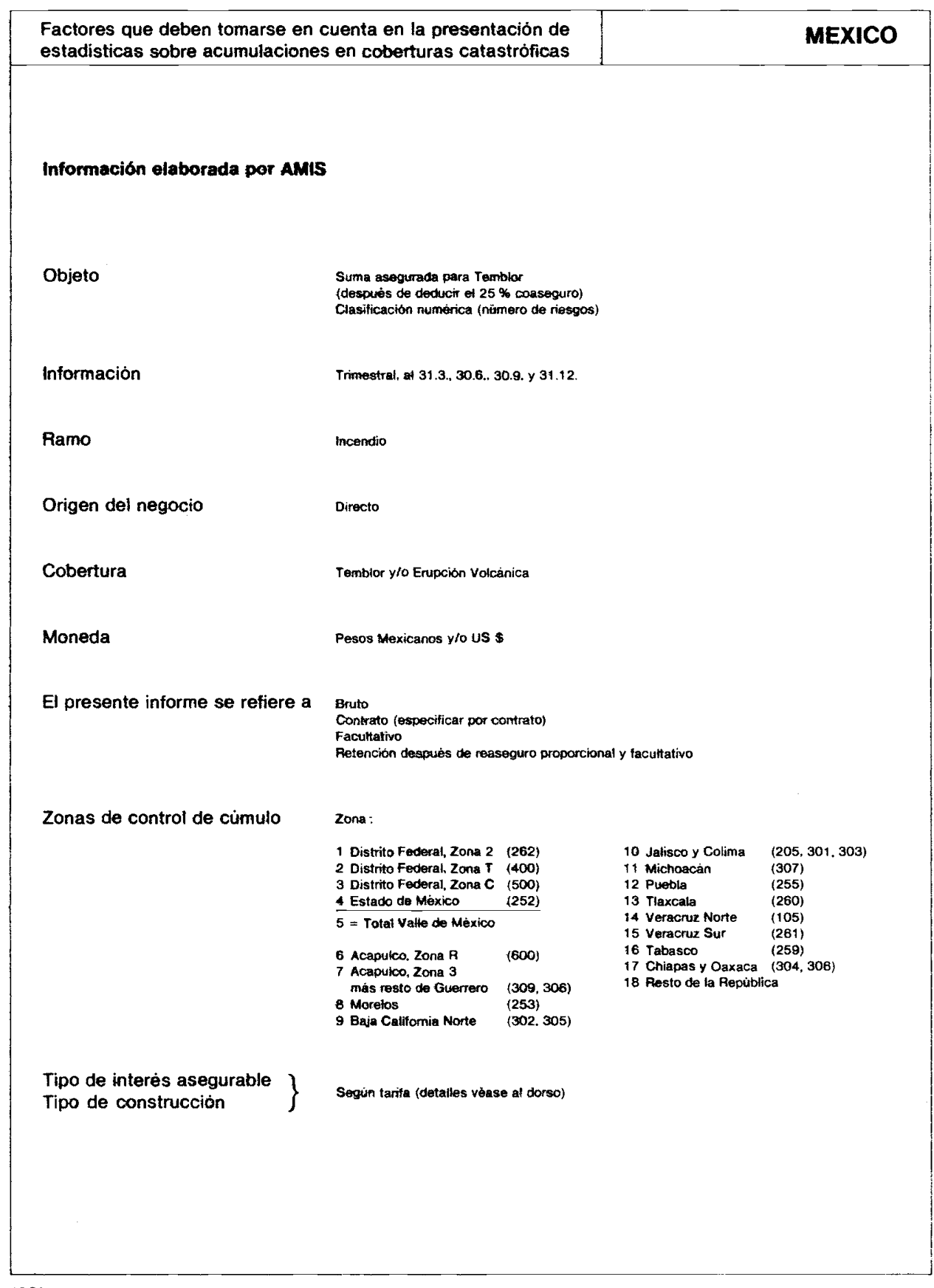

12.81 


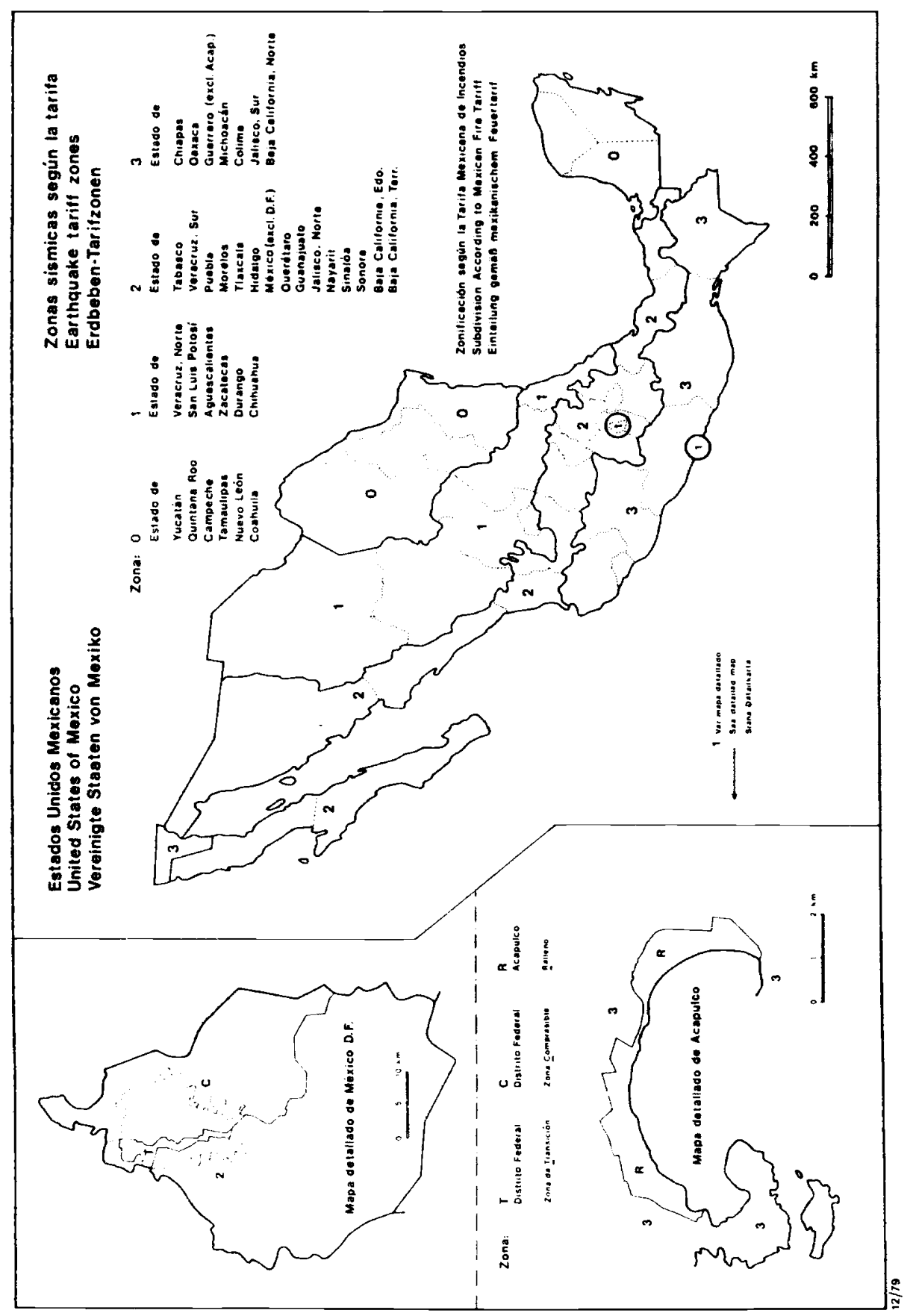




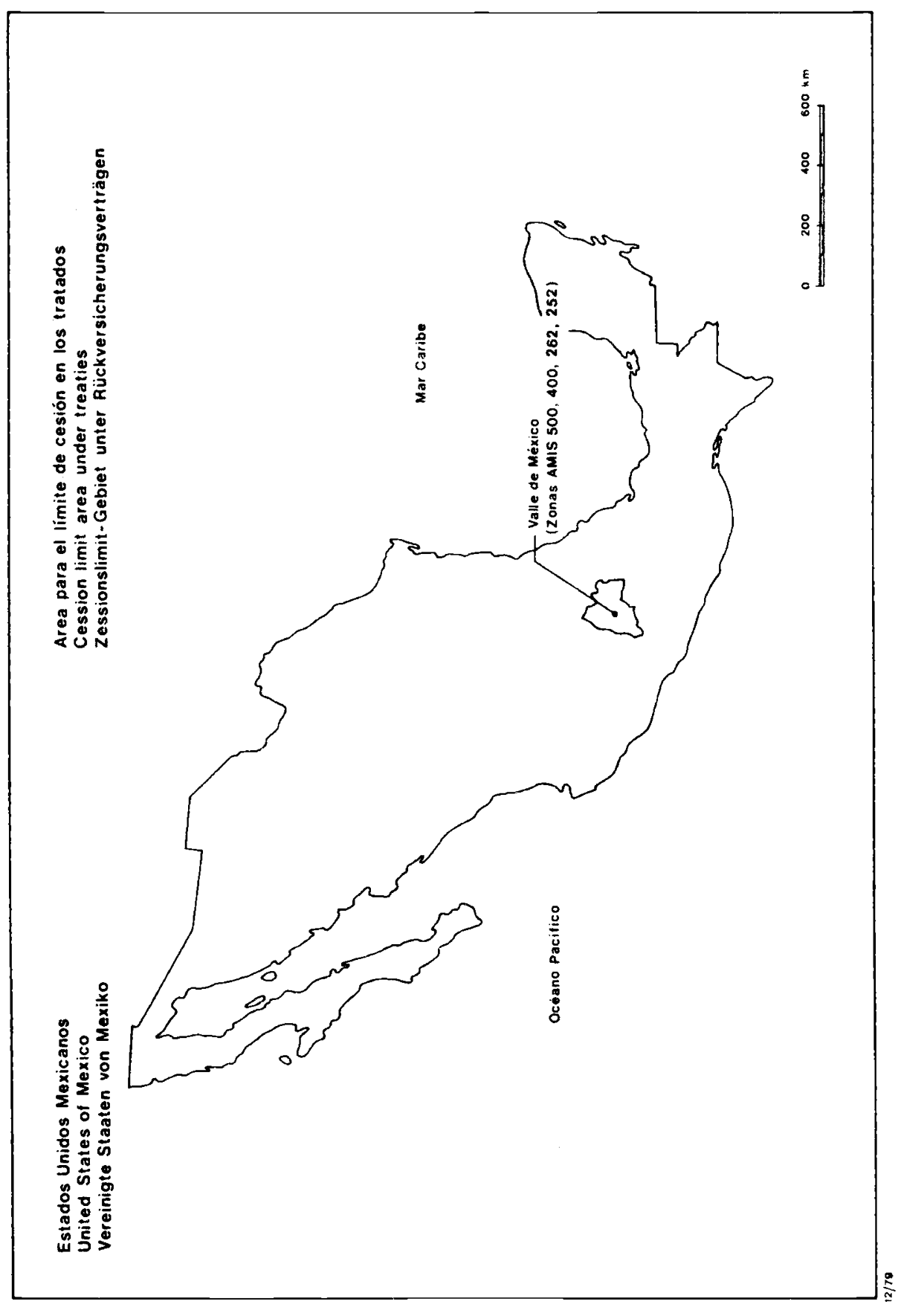




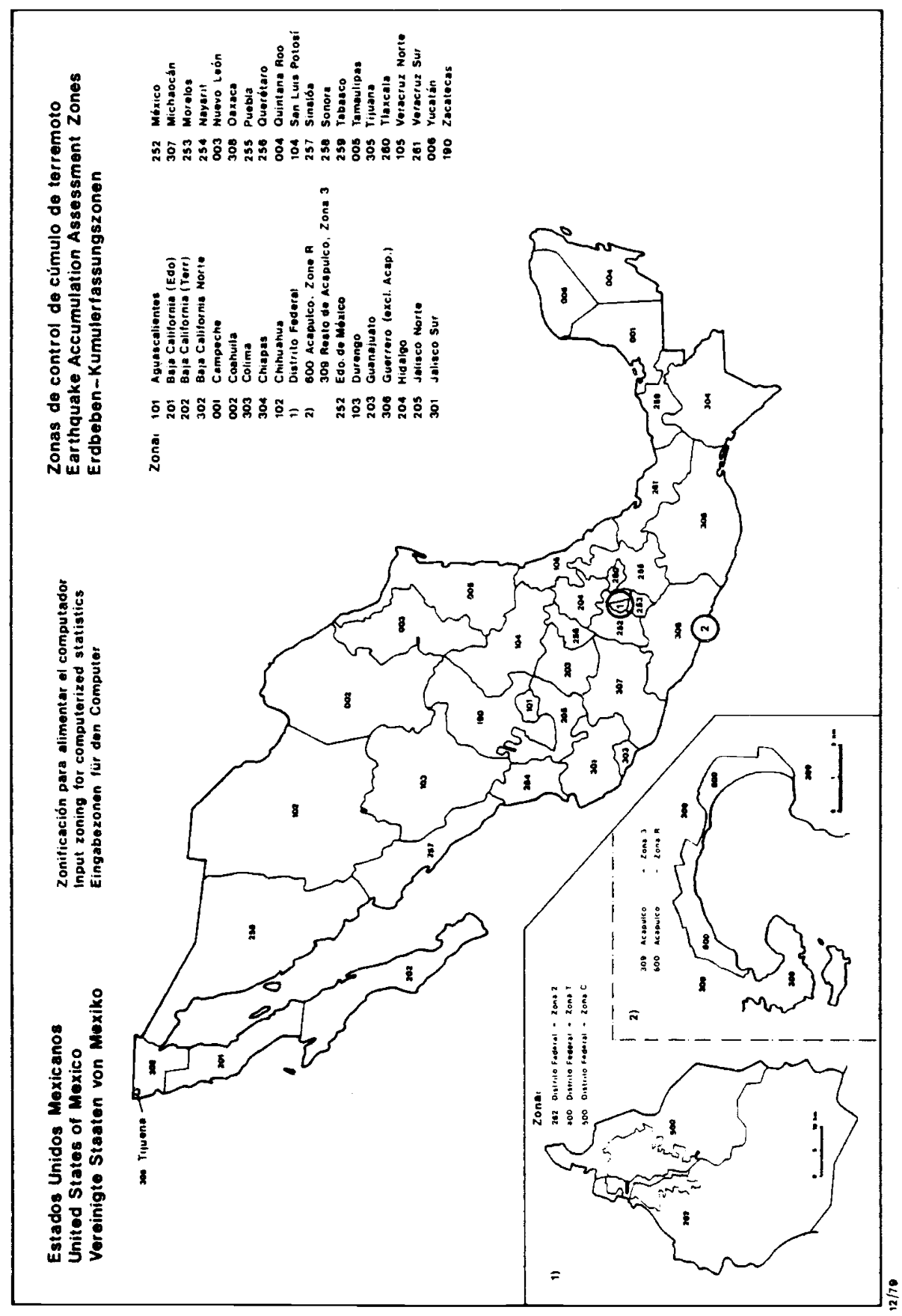




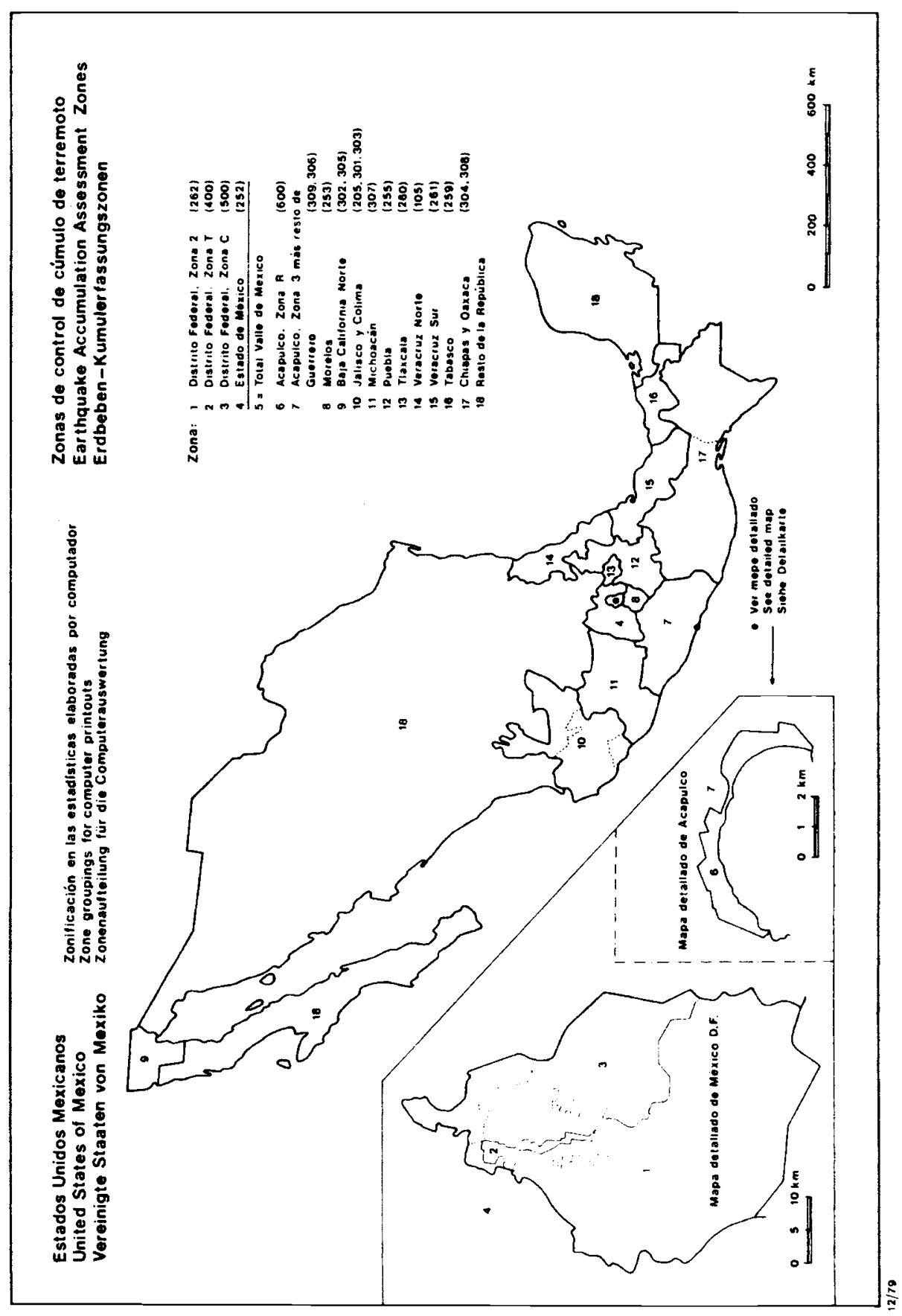




\section{Enclosure 4 : Countries with state participation in the cover of natural disasters}

Federal Republic of Germany: Obligatory inclusion of earthquake and flood cover in the state monopoly buildings insurance in Baden-Württemberg ; financed by obligatory, claims-based additional premiums, with state guarantee.

France : Cover of natural disasters in property and motor own damage insurance required by law as of 14th August 1982 ; financed by obligatory additional premiums of $1-5 \%$; state reinsurance; declaration of natural disaster by interministerial decree.

Japan: Private earthquake insurance supplementary to fire insurance for private and business buildings with obligatory state reinsurance and approx. $85 \%$ state participation in the overall loss limit of at present approx. $\$ 5,000$ million.

Jugoslavia: In certain of the republics state reserve funds for natural disasters, financed by obligatory additional premiums (e.g. $5 \%$ of fire premium for earthquakes) since 1975 .

New Zealand: State natural disaster insurance under the "Earthquake and War Damage Act of 1944 " as an automatic supplement to fire cover, limited though to the actual value ; financed by additional premium; capacity at present approx. $\$ 500$ million.

Norway : State support fund for natural disasters ; limit of indemnity per policy approx. $\$ 30,000$.

Rumania: State cover for natural disasters for private property and co-operatives as supplement to the obligatory fire cover for buildings; coverage on an actual value basis; financed by a uniform premium; similar situation in other Eastern bloc countries.

Switzerland: State fund (since 1903) for non-insurable damage to private property as a result of natural disaster; financed by casino income.

State natural disaster cover (limit per event at present approx. SwF 40 million) by the majority of the cantonal building/fire insurance monopolies; reinsurance coverage at present approx. SwF 100 million; in addition, private fire insurers' natural disaster pool, presently also limited to SwF 100 million.

Spain : State disaster cover ("Consorcio de Compensación de Seguros", since 1954) with participation by the insurance industry; financed by obligatory additional premiums of $1-10 \%$ on property, marine, and liability, accident and motor insurances; covers damage of " extreme" nature especially damage caused by earthquake (intensity VII and above, on the Wood-Neumann scale), flood, whirlwind and landslide, as well as by riot and civil commotion in times of peace; disasters extending nationwide are excluded as such but can be covered from case to case by decree and can be indemnified with the aid of state subsidies.

USA : State flood insurance under the National Flood Insurance Act of 1968 on an initially heavily reduced premium basis; participation in this scheme only possible on a community basis; at present about 17,000 communities with almost two million individual policies and a sum insured of $\$ 100,000$ million. 